\title{
The Moderating Effect of Emotional Dysregulation on the Relationship Between Teacher Efficacy and Job Stress of Teachers in Early Childhood Education and Care
}

\author{
Kyung-Sook Lee ${ }^{1}$, Jin-Young Chae ${ }^{2}$, Myung-Sik Kim³ ${ }^{3}$ JinAh Park ${ }^{4}$, Jeong Min Lee ${ }^{2}$ \\ Department of Rehabilitation, Hanshin University, Osan, Korea ${ }^{1}$ \\ Department of Child Studies, Chonbuk National University, Jeonju, Korea ${ }^{2}$ \\ Department of Counseling Psychology, Jeonju University, Jeonju, Korea ${ }^{3}$ \\ Sewon Infant Child Development Center, Seoul, Korea ${ }^{4}$

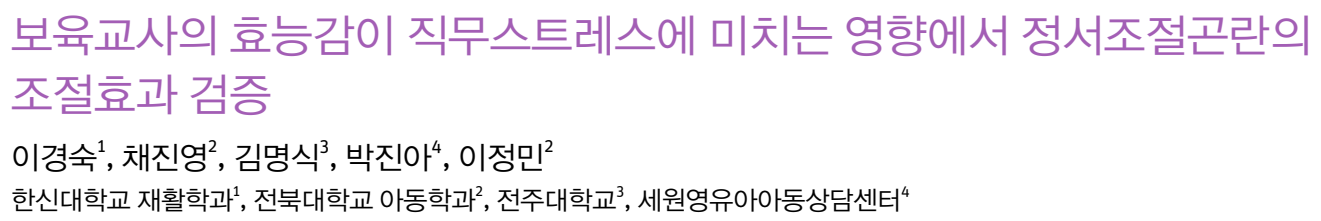

Objective: This study investigated the moderating effect of emotional dysregulation on the relationship between teacher efficacy and job stress among teachers in the Early Childhood Education and Care (ECEC).

Methods: The participants included 586 ECEC teachers from 99 centers in Seoul, Gyeonggi-do, Daejeon, Chungcheong-do, Jeolla-do, and Gyeongsang-do. The data were analyzed through frequencies, percentages, and Pearson's correlations using SPSS 21.0 (IBM Co., Armonk, NY). To analyze the moderating effect, Ping's (1996) two-step approach was used via AMOS 20.0 (IBM Co., Armonk, NY).

Results: The main findings are as follows. First, the mean scores of ECEC teacher efficacy and job stress showed above the average, and the mean score of emotional dysregulation was the nearly average. Second, fit statistics indicated that the proposed model, as revised, provided an acceptable fit to the sample data. This proposed model showed that the emotional dysregulation of teachers in ECEC had a moderating effect on the relationship between teacher efficacy and job stress.

Conclusion: These findings imply that the ECEC teachers showed the higher level of self-trust and self-confidence than average regarding their own work, and suffered from the work overload. Also, the positive and supportive working environment would help the ECEC teachers to reduce their emotional dysregulation. In addition, there was a moderating effect of the ECEC teachers' emotional dysregulation on the relationship between teacher efficacy and job stress. These findings imply that the workshop or counselling programs need to be provided to teachers in order to help control their emotion dysregulation and reduce their job stress.

Keywords: teacher efficacy, job stress, emotional dysregulation, moderating effect, teacher in ECEC

Corresponding Author: Jin-Young Chae, Department of Child Studies, Chonbuk National University, 567 Baekje-daero, Deokjin-gu, Jeonju, Jeonbuk, 54896, Korea

E-mail: jychae@jbnu.ac.kr
(c)The Korean Association of Child Studies

This is an Open Access article distributed under the terms of the Creative Commons Attribution Non-Commercial License (http:// creativecommons.org/licenses/by-nc/4.0) which permits unrestricted noncommercial use, distribution, and reproduction in any medium, provided the original work is properly cited. 


\section{서론}

정부가 복지정책의 일환으로 무상보육을 실시하여 이른 시기 부터 기관에 맡겨져 보육교사에게 대리양육을 경험하는 영 유아가 증가함에 따라 보육시설도 급증하였다. 최근 10 년 동 안 1 만 7천 여 개가 신설되었고(Ministry of Health and Welfare [MOHW], 2016a), 이로 인해 같은 기간 동안 보육교직원이 2 배 이상 증가하였다. 그럼에도 불구하고 여전히 교사 수급은 원활하지 못한 상황이며, 온라인상에서는 짧은 기간 안에 자 격증을 취득하여 취업이 보장된다는 광고성 기사가 즐비하 여 충분한 양성교육기간을 거치지 않은 보육교사가 많이 배 출되고 있다. 다른 교육 관련 국가자격증에 비해 비교적 쉽게 자격증 취득이 가능하다 보니 충분한 양성기간을 거치지 않 고 보육교사의 역할 및 직무에 대한 이해와 준비가 덜 된 상 태에서 현장에 투입되는 경우, 직무스트레스에 취약할 가능 성이 높다(Yoo, Kim, Kang, Park, \& Hwang, 2011). 직무스트레 스가 높은 교사는 좌절, 공격성, 불안, 회피 행동, 결근 등의 심 리행동을 보여 학습자에게도 부정적인 영향을 미친다(Kaiser \& Polczynski, 1982). 과다한 업무나 낮은 교사효능감 등으로 인한 직무스트레스는 직업만족을 저하시키는 원인으로 교사 로서 기대되는 역할 수행에 부정적인 영향을 미친다(Collie, Shapka, \& Perry, 2012). 불행히도 최근 들어 보육교사로서는 하지 말아야 할 일들이 보육현장에서 계속 발생하여 영유아에 게 매우 커다란 정신적, 육체적 피해를 주는데, 이러한 보육교 사의 부정적인 행동에 대해 높은 직무스트레스가 주된 원인으 로 지목되고 있다. 이러한 보육교사의 직무스트레스는 보육의 질을 저하시킬 뿐 아니라 다수의 우수한 보육교사의 사기를 떨어뜨리는 요인이 되기도 하고 이로 인해 이직을 고려하게 되며(Yoon \& Noh, 2013), 무엇보다도 영유아 발달에 매우 부 정적인 영향을 미치게 되므로 보육교사의 직무스트레스에 영 향을 미치는 요인과 이를 낮추기 위한 방안은 꾸준히 연구되 어야 할 것이다.

보육교사는 한 개인의 생애 첫 교사로서 신체적 돌봄과 정 서적 양육을 제공하고 육체적, 감각적인 방법으로 세상에 대 해 배워 나아갈 수 있도록 눈높이가 맞는 교육을 제공해야 하 며, 정직함 및 공정함을 통해 일상생활에 무엇이 옳은지에 대 한 모델링을 보여줘야 하는 등 발달에 결정적인 이 시기의 영 유아에게 부모 못지않게 많은 영향을 미치는 중요한 역할을 담당한다(Freeman \& Feeney, 2016; Recchia, 2016). 그러나 이러 한 보육교사직은 동시에 육체적, 정신적 소진이 높은 직종이 며 영유아를 직접적으로 돌보는 일 이외에도 매일 학부모와
도 상호작용해야 하며 서류업무처리, 원 행사 계획 및 실행 등 과다한 업무에 비해 열악한 근무환경 및 보수 등으로 스트레 스가 많은 직종 중 하나이다(Klassen, Foster, Rajani, \& Bowman, 2009; Kwon, 2009). 또한 주로 영유아나 학부모와의 대인관계 가 위주인 역할을 수행함에 있어서 실제로 느끼는 정서와 다 르더라도 긍정적인 정서를 많이 표현해야 하는 정서노동이 강 조되는 직업이다(Cukur, 2009; Kovess-Masfety, Rios-Seidel, \& Sevilla-Dedieu, 2007).

교사의 직무스트레스는 교사로서 직무를 수행함에 있어 자 신의 교육적 시도가 이루어지지 않은 것과 관련된 좌절감 또 는 학습자, 동료, 학부모 등과의 대인갈등으로 인해 심리적 안 녕감이 위협을 받아 개인의 심리적, 생리적 항상성이 어긋나 는 것을 의미한다(Leach, 1984; Margolis, Kroe, \& Quinn, 1974). 공포, 두려움, 불안, 짜증, 분노, 고민, 슬픔, 우울 등 부정적인 정서경험과 밀접한 관계가 있는 직무스트레스는 직무를 수행 하는 과정에서 잠재적인 역기능의 주된 원인이며(Motowidlo, Packard, \& Manning, 1986), 육체적, 정신적 소진을 예측하는 원인이기도 하다(Schwarzer \& Hallum, 2008). Shin (2004)은 교 사의 직무스트레스에 관한 초기 연구들은 자극에 대한 반응으 로써의 직무스트레스를 살펴보았지만, 점차 직무스트레스에 대한 교사 개인의 지각 또는 조절과 같은 인지적 평가 과정을 강조하는 추세라면서, 어린이집에서 발생하는 직무와 관련된 자극이나 요구가 교사의 심리적 안녕을 위협할 때 교사가 이 를 지각하고 평형 상태를 유지하기 위해 자신이 가진 대처 기 제나 개인의 능력에 의해 조절된 결과로 나타내는 것을 보육 교사의 직무스트레스라고 새롭게 정의하였다. 최근 발표된 한 보고서에 따르면 보육교사의 직무스트레스를 중복응답하게 하여 가중치를 주어 순위를 분석한 결과, 서류업무, 보수, 휴 가제도, 여가 및 전문성 향상 시간 부족, 교사 대 영유아 비율, 부모와의 관계, 영유아와의 상호작용, 활동 계획 및 준비, 원 장 및 동료와의 관계, 물리적 근무환경 등의 순으로 직무스트 레스를 많이 받는 것으로 나타났다(K.-S. Lee, Kim, Chae, Park, \& Yoon, 2015). 영유아 교사들이 직무 관련 스트레스를 많이 받게 될 경우 양질의 보육을 제공하기 어려우며, 아동학대의 확률이 높아지기도 한다(Y.-M. Kim \& Kang, 2015; Crouch \& Behl, 2000; D. M. Seo \& Yeun, 2016)는 선행연구 결과로 미루 어 볼 때 기관에서 부모 역할을 하는 보육교사가 경험하는 스 트레스는 영유아에게 부정적인 영향을 미치는 위험요인임에 틀림없다. 따라서 영유아의 하루 일과 중 부모보다도 더 많은 시간을 함께 하는 보육교사의 직무스트레스에 영향을 미칠 것 으로 예상되는 관련요인들을 살펴봄으로써 보육교사의 직무 
스트레스를 낮출 수 있는 현실적인 대책 마련을 위한 정책적 제안을 하고자 한다.

우선 보육교사의 직무스트레스와 관련된 요인으로 교사 효능감을 고려해볼 수 있다. 교사효능감은 심지어 까다롭고 동기부여가 잘 되지 않는 학습자라도 배움과 참여에 대해 교 사로서 원하는 결과를 이끌어낼 수 있다는 자신의 능력에 대 한 평가를 바탕으로 한 믿음이며 자신감을 의미한다(Bandura, 1977; Gibson \& Dembo, 1984). 교사가 효능감이 높은 경우, 연령이 낮은 영유아라도 배움에 있어 자유로운 의사결정권 을 주어 효과적이고 민주적으로 학급을 운영한다(TschannenMoran, Hoy, \& Hoy, 1998). 또한 학급 운영을 계획, 준비, 실천 하는 일에 탁월한 능력을 보이며, 직무를 수행할 때 원하는 방 향대로 이루어지지 않거나 장애가 있더라도 잘 버티며 탄력 적으로 처리를 한다(Goddard, Hoy, \& Hoy, 2000; TschannenMoran \& Hoy, 2001). 보육교사직은 영유아 돌봄, 발달에 적합 한 교수법 적용, 영유아 및 부모들과의 상호작용, 동료들과의 협력, 행정 처리 등 여러 가지 능력이 동시에 요구되는 직업으 로 이렇게 다양한 역할을 동시에 수행하는 과정에서 자신의 능력에 대한 믿음과 자신감에 대한 균형이 이루지지 않는다면 직무스트레스에 노출되기 쉽다(Schwarzer \& Hallum, 2008). 국 내외의 연구를 통해 유아교육 및 보육현장에서 보육교사 또는 유치원교사의 교사효능감은 직무스트레스에 영향을 미치는 유의한 예측요인으로, 교사효능감이 높으면 직무스트레스가 낮다고 일관적으로 보고되고 있다(S. Y. Cho, 2005; Choi, 2015; H.-M. Lee, 2009; Schwarzer \& Hallum, 2008). 수년간 이루어 진 연구에 의하면 교사의 역할과 책임감에 대한 사회적 요구 와 기대가 높아짐에 따라 교사의 효능감은 다면적으로 측정되 고 이해되어야 한다는 주장이 제기되어 왔다(Bandura, 1977; Chan, 2008; Tschannen-Moran \& Hoy, 2001). Bandura (2006) 역 시 교사 효능감 척도(Teacher Self-Efficacy Scale [TSES])를 개발 하면서 교사의 효능감을 측정할 때에는 단일영역이 아닌 개인 의 능력을 다양한 영역에서 측정해야 한다고 주장하였다. 이 에 보육교사의 효능감을 다면적인 측면에서 측정하고 직무스 트레스 또한 다면적으로 측정하여, 이 변인들 간의 상관관계 및 영향의 관계를 살펴봄으로써 보육교사의 효능감과 직무스 트레스에 대한 이해의 폭을 넓히고자 한다.

보육교사의 직무스트레스에 영향을 미치는 또 다른 요인 으로 정서조절곤란(emotional dysregulation)을 살펴볼 필요가 있다. 정서조절은 자신의 기분을 고조시키거나 부정적인 상 태의 정서를 유지시키거나 저하시키는 노력을 의미하는데(J.Y. Lee \& Kwon, 2007), 개인의 심리적 안녕과 성공적인 역할수
행을 결정하는 중요한 요인이다(Cicchetti, Ackerman, \& Izard, 1995). 스트레스 상황에서 부정적 정서조절 기대치, 즉 부정적 인 기분을 조절하는 개인의 능력에 대한 믿음이 높으면 스트 레스 및 심리적 괴로움을 감소시키는 등 정서조절능력은 스 트레스 수준에 영향을 미친다(Aldea \& Rice, 2006; Catanzaro $\&$ Laurent, 2004). 그러나 이러한 능력의 역기능적인 면인 정 서조절곤란은 경계성 인격장애 등 여러 가지 정신적 장애를 나타내는 행동과 관련이 매우 높으며(Gratz \& Roemer, 2004), 정서조절에 곤란을 겪으면 인지적 기능이 손상될 뿐 아니 라 사회적 또는 직업적인 기능에 부정적인 결과를 초래한다 (Kring \& Werner, 2004). 또한 스트레스를 더 잘 받는 경향으 로 나타나기도 하고(Reid, Bramen, Anderson, \& Cohen, 2014) 공격적인 행동의 원인이 되기도 한다(Herts, McLaughlin, \& Hatzenbuehlelr, 2012). 그동안 교사의 직무스트레스에 관한 국 내외 연구는 개인적인 특성을 간과한 채 주로 환경적인 요인 에 초점을 맞추어 이루어져 왔다(Mearns \& Cain, 2003). 특히 국내에서는 교사를 대상으로 한 정서조절곤란에 대한 연구 가 매우 드문 실정인데, 중등교사의 정서조절을 연구한 $\operatorname{Lim}$ 과 $\mathrm{Do}$ (2014)에 의하면 교사가 정서조절에 곤란을 겪을수록 직무 스트레스는 높아진다고 하였다. 초중등교사를 대상으로 실시 한 국외 연구에 의하면, 부정적 정서조절 기대치가 높은 교사 는 직무스트레스에 보다 적극적으로 대처를 하여 스트레스를 완화시키고, 직무 수행에도 높은 적응력을 보이는 것으로 나 타났다(Mearns \& Cain, 2003). 이러한 선행연구 결과를 미루어 볼 때, 보육교사의 경우에도 정서조절에 문제가 있다면, 즉 정 서조절곤란을 겪는다면 같은 상황에서라도 스트레스를 더 많 이 받을 것으로 예측한다. 정서조절능력이 발달한 교사는 유 아와 긍정적인 관계를 맺는다는 연구결과(Park, 2013)와 유아 와 긍정적인 관계를 맺지 못하면 스트레스를 더 많이 받는다 는 연구결과(Klassen et al., 2009)를 고려해 본다면 교사의 정서 조절은 직무스트레스에 영향을 미칠 것으로 예상되기 때문이 다. 따라서 보육교사를 대상으로 이들의 관계를 국내 최초로 검증해 보고자한다.

한편, 근래 의학 또는 심리 및 사회학 연구 분야에서 독립변 인과 종속변인 관계를 더 잘 설명하기 위해 매개변인 또는 조 절변인이라는 제 3 의 변인을 사용하는 경우가 증가하고 있으 며, 독립변인과 종속변인간의 관계가 제 3 의 변인의 수준에 따 라 달라질 때 이 제 3 의 변인을 조절변인라고 한다(MacKinnon \& Leucken, 2008). 이때 조절변인은 독립변인과의 상호작용을 통해 독립변인이 종속변인에 미치는 영향을 강화시키기도 하 고 완화시키기도 한다. 조절변인의 조절효과를 검증하기 위해 
서는 조절변인이 독립변인과 종속변인 간의 관계에서 어떤 역 할을 할 것인가를 가정해야 하는데, 조절효과에는 이론적으 로 강화효과, 완화효과, 대립효과 등 세 가지 유형이 있다(Bae, 2015). 앞서 고찰한 선행연구를 종합하여 보면, 보육교사의 효 능감은 직무스트레스에 부적 영향을 미칠 것이며, 정서조절곤 란은 직무스트레스에 정적 영향을 미칠 것으로 가정할 수 있 다. 이는 종속변인에 부적 영향을 미치는 독립변인과 정적 영 향을 미치는 또 다른 독립변인, 즉 조절변인이 상호작용을 한 경우 종속변인에 정적영향을 미칠 것이라는 완화효과에 해당 되는 것(Bae, 2015)이며, 독립변인과 조절변인의 상호작용항 이 포함된 경우, 독립변인인 보육교사의 효능감이 종속변인인 직무스트레스에 미치는 영향의 효과가 줄어드는 것을 의미한 다. 보육교사는 언제나 긍정적인 정서만을 느낄 수 없는 상황 에서도 기관에서 보육교사로서 표현되기를 기대하는 정서와 보육교사 자신이 느끼는 정서의 차이로 인해 정서적 불일치를 경험하게 되는 경우에 이러한 불일치를 정서조절을 통해 해결 해야 한다(Chang, 2009; Kwon, 2009). 정서조절능력은 효능감 과 정적 상관이 있다는 선행연구결과(Han, Park, Kim, Oh, Jin, \& Kang, 2008; Suveg \& Zeman, 2004)와 보육교사효능감과 정 서조절능력이 직무스트레스에 각각 미치는 영향으로 미루어 보았을 때, 보육교사의 높은 효능감이 직무스트레스를 낮춘다 하더라도 정서조절에 곤란을 겪는다면 이 변인들의 상호작용 으로 인해 교사효능감이 직무스트레스에 미치는 영향이 줄어 들어 직무스트레스를 높일 것으로 추측할 수 있다. 이를 바탕 으로 보육교사의 효능감이 직무스트레스에 미치는 영향을 보 육교사의 효능감과 정서조절곤란의 상호작용이 완화시키는 지, 그리하여 정서조절곤란은 이 두 변인의 관계에서 조절효 과를 보이는지를 확인해보고자 한다.

이상의 내용을 종합하면, 보육교사의 직무스트레스의 수준 을 낮출 수 있는 요인으로 교사효능감과 증가시킬 수 있는 요 인으로 정서조절곤란을 살펴보고, 보육교사효능감이 직무스 트레스에 영향을 미치는 관계에서 정서조절곤란의 조절효과 가 있는지를 살펴봄으로써, 그동안 이루어지지 않은 이 세 변 인의 관계에 대한 기초자료를 제공할 수 있을 것으로 예상한 다. 아울러 이와 관련된 시사점을 찾아 보육의 질적인 향상을 위한 실효성 있는 정책수립을 위한 틀을 마련하고자 한다. 이 러한 연구목적으로 설정한 연구문제는 다음과 같다.

\section{연구문제 1}

보육교사의 효능감, 정서조절곤란 및 직무스트레스의 수준은 어떠한가?

\section{연구문제 2}

보육교사의 정서조절곤란은 교사효능감과 직무스트레스 간 의 관계를 조절하는가?

\section{연구방법}

\section{참여자}

서울, 경기, 대전, 충청, 전라, 경상지역에서 임의 선정한 총 99 개 어린이집 원장의 협조를 받아 설문조사의 취지에 동의한 보육교사를 797명에게 직접 방문 또는 우편을 통해 설문지를 배포하고 수거하였다. 656 부가 회수되어 회수율은 $82.3 \%$ 이었 으나, 부실응답을 한 응답자의 설문지 70 부를 제외하고 586부 의 자료를 최종적으로 분석하였다. Table 1 과 같이, 연령별로 는 만 41-45세가 23.5\%를 차지해 가장 많았고, 만 31-35세가 $21.3 \%$, 만 36-40세가 $17.1 \%$ 이었다. 근무경력별로는 1-3년이 $24.2 \%$ 이었으며, 3-5년이 $19.3 \%, 7-10$ 년이 $18.6 \%$ 이었다. 근무 기관 유형에 따라서는 민간어린이집 종사자가 $30.7 \%$ 로 가장 많았고, 국공립 $(27.0 \%)$, 가정 $(25.8 \%)$ 어린이집이 그 뒤를 이었 다. 최종학력은 2-3년제 대학 졸업자가 전체 $54.9 \%$ 로 가장 많 았고, 4 년제 대학 졸업자는 $31.4 \%$ 이었다.

\section{연구도구}

\section{직무스트레스}

Shin (2004)이 보육교사 직무스트레스를 측정하기 위해 어린 이집의 다양한 직무 상황에서 발생하는 포괄적인 스트레스 요 인을 포함시켜 개발한 도구를 사용하였다. "우리 어린이집의 운영은 바람직한 보육의 실제와 맞지 않는다.” 등의 원장의 지 도력 및 행정적 지원 부족과 관련된 11 개 문항, “환경정리, 연 락업무, 차량지도 등 잡무가 너무 많다.” 등의 업무 과부하와 관련된 8개 문항, "교사들 간의 의사소통이 잘 이루어지지 않 는다." 등의 동료와의 관계와 관련된 5 문항, "부모들은 어린이 집 일에 지나치게 관여를 한다.' 등의 학부모와의 관계와 관련 된 3문항 등 총 4 개 하위요인, 27 개 문항으로 구성되어 있다. 각 문항은 전혀 스트레스를 받지 않는다를 1점, 매우 스트레스 를 받는다를 5점으로 하는 5점 리커트 형식으로 이루어져 있 으며, 아동 및 상담 관련 전공 교수 및 박사 5 인에 의해 내용타 당성을 검증하였고, 특별한 수정 없이 원도구 그대로 사용하 
Table 1

Demographics of the Participants

\begin{tabular}{|c|c|}
\hline Variable & $N(\%)$ \\
\hline \multicolumn{2}{|l|}{ Ages } \\
\hline $20-25 y r s$ & $71(12.1)$ \\
\hline $26-30 y r s$ & $79(13.5)$ \\
\hline $31-35 y r s$ & $125(21.3)$ \\
\hline $36-40 y r s$ & $100(17.1)$ \\
\hline $41-45 y r s$ & $138(23.5)$ \\
\hline Over 46yrs & $73(12.5)$ \\
\hline \multicolumn{2}{|l|}{ Center type } \\
\hline Public & $158(27.0)$ \\
\hline Private & $180(30.7)$ \\
\hline Home type & $151(25.8)$ \\
\hline Corporation & $71(12.1)$ \\
\hline Nonprofit organization & $26(4.4)$ \\
\hline \multicolumn{2}{|l|}{ Teaching experiences } \\
\hline Less than $1 \mathrm{yr}$ & $55(9.4)$ \\
\hline $1-3 y r s$ & $142(24.2)$ \\
\hline $3-5 y r s$ & $113(19.3)$ \\
\hline $5-7 y r s$ & $75(12.8)$ \\
\hline $7-10 y r s$ & $109(18.6)$ \\
\hline More than $10 y r s$ & $92(15.7)$ \\
\hline \multicolumn{2}{|l|}{ Education level } \\
\hline High school graduates & $48(8.2)$ \\
\hline Two/Three-years college graduate & $322(54.9)$ \\
\hline Four-year college graduates & $184(31.4)$ \\
\hline Beyond graduate school & $22(3.8)$ \\
\hline Etc. & $10(1.7)$ \\
\hline
\end{tabular}

Note. $N=586$.

였다. 점수가 높을수록 해당 영역의 스트레스가 더 높음을 의 미하며, Cronbach의 $\alpha$ 계수는 하위요인 순서대로 .91, $.82, .84$, .71이며, 전체적으로는 .93이었다.

\section{보육교사 효능감}

Y. H. Kim과 Kim (2008)이 Bandura (2006)의 교사 자기 효능 감 척도(TSES)를 번역하고 수정 및 보완한 도구를 사용하였 다. 이 도구는 국내 보육교사에게 맞게 요인분석을 거쳐 현직 교사와 예비교사를 대상으로 타당성이 검증된 것이며, 다면적 인 능력과 역할이 요구되는 영유아교사의 직장 내에서의 생활 과 역할을 잘 반영하는 것으로 알려져 있다. 이 연구에서는 현 직 교사와 관련된 내용만 사용하였으며, 아동 및 상담 관련 전
공 교수 및 박사 5 인에 의해 내용타당성을 검증받아 원도구 그 대로 사용하였다. "유아들이 교실 내의 규칙을 지키도록 할 수 있습니까?” 등의 가정연계 및 긍정적 학습 환경 조성에 관한 13 문항, "다루기 어려운 유아들을 효과적으로 지도 할 수 있 습니까?” 등의 교수방법에 관한 7문항, "어린이집 유아와 지역 사회단체들(예: 노인정, 소방서, 경찰서 등)을 연계 시킬 수 있 습니까?” 등의 지역기관 연계에 관한 4 문항, “어린이집과 관련 된 중요한 일에 자유롭게 본인의 의견을 표현 하실 수 있습니 까?” 등의 의사결정 참여에 관한 5 문항 등 총 4 개 하위요인, 29 문항으로 구성되어 있다. 전혀 그렇지 않다를 1점, 매우 그렇 다를 5점으로 하는 리커트 형식으로 이루어져 있으며, 점수가 높을수록 교사로서의 자신의 능력을 높게 평가함을 의미한다. Cronbach의 $\alpha$ 계수는 하위요인 순서대로 $.88, .73, .86, .63$ 이며, 전체적으로는 .91이었다.

\section{정서조절곤란}

기존에 사용된 도구보다 정서조절곤란을 더 포괄적인 측면에 서 다차원적으로 측정하기 위해 Gratz와 Roemer (2004)가 개 발한 도구를 Y. Cho (2007)가 국내에서 타당화 시킨 한국판 정서조절곤란 척도(Korean Difficulties in Emotion Regulation Scale [K-DERS])를 사용하였다. 이 도구는 6 개 하위요인 35 문 항으로 구성되어 있다. "나는 화가 나거나 기분이 나쁘면, 자 제하지 못한다." 등의 충동통제곤란에 대한 5 문항, "내가 어떻 게 느끼고 있는지를 정확하게 안다.” 등의 정서에 대한 주의와 자각 부족과 관련된 7문항, "나는 화가 나거나 기분이 나쁘면, 그렇게 느끼는 나 자신에게 화가 난다" 등의 정서에 대한 비수 용성과 관련된 8 문항, "내 감정을 이해하기 어렵다." 등의 정 서적 명료성 부족과 관련된 3문항, "나는 화가 나거나 기분이 나쁘면, 그 상태에 빠져 허우적거리는 것이 내가 할 수 있는 모 든 것이라고 믿는다.” 등의 정서조절전략접근 제한과 관련된 6문항, "나는 화가 나거나 기분이 나쁘면, 다른 일들에 집중하 기가 어렵다.” 등의 목표지향적 행동의 어려움과 관련된 4 문 항 등 6 개 하위요인 35 문항을 사용하였다. 아동 및 상담 관련 전공 교수 및 박사 5 인이 내용타당성을 검증하여 원도구를 수 정 없이 그대로 사용하였다. 각 문항은 전혀 아니다를 1점, 항 상 그렇다를 5점으로 하는 리커트 형식으로 구성되어 있다. 긍 정적 의미의 문항은 역채점을 하였으며, 점수가 높을수록 정 서조절의 곤란 상태가 높음을 의미한다. Cronbach의 $\alpha$ 계수는 하위요인 순서대로 $.83, .78, .87, .64, .83, .81$ 이며, 전체적으로 는 .94이었다. 


\section{연구절차}

전라지역의 어린이집 1 곳을 임의 선정한 후 직접 방문하여 원 장에게 본 연구의 취지 및 절차를 설명하고 조사에 참여하기 를 동의한 보육교사 8 명을 대상으로 예비조사를 실시하였다. 질문지 응답과정에서 특별히 문제점이 발견되지 않아 본조사 를 진행하였다. 서울, 경기, 대전, 전라, 경상지역에서 연구에 참여할 기관을 임의로 선정하여 원장에게 유선상으로 협조를 구한 후 99개 기관에 우편 또는 직접 방문을 통해 총 797부의 설문지를 개별봉투와 함께 배포하였다. 응답이 완료된 설문지 는 응답자에 의해 개별봉투에 넣어져 밀봉되었고, 우편 또는 직접 수거 방법으로 656 부를 회수되었으며 회수율은 $82.3 \%$ 이었다. 이 가운에 부실응답이 포함된 설문지를 제외하고 총 586 명이 응답한 자료가 최종 분석 대상이 되었다.

\section{자료분석}

수집된 자료는 SPSS 21.0 (IBM Co., Armonk, NY)과 AMOS 20.0 (IBM Co., Armonk, NY)을 이용하여 분석되었다. 보육교 사의 일반적 배경을 파악하기 위해 빈도와 백분율을, 각 도구 의 신뢰도 검증을 위해 Cronbach의 $\alpha$ 계수를 산출하였다. 각 변 인들의 정규성은 왜도와 첨도를 통해 알아보았고, 상관관계는 Pearson의 적률상관관계 분석으로 살펴보았다. 회귀분석을 이 용해 조절효과를 검증하였던 과거와는 달리 근래에는 독립변 인과 조절변인이 모두 연속변인일 때 구조방정식을 이용한 조 절효과 검증을 더 권장하는 분위기이다(Schumacker \& Lomax, 2015). 따라서 본 연구에서는 구조방정식 모형을 이용한 Ping (1996)의 2단계 접근방식으로 독립변인과 조절변인의 상호 작용효과를 분석하였다. 상호작용항은 단일지표로 생성하였 으며, 주효과변인과 조절효과변인의 다중공선성의 가능성 을 배제하기 위하여 지표변인들을 각각 평균중심화하였다(Y. S. Seo, 2010). 모형의 적합지수는 GFI (Goodness-of-Fit Index), CFI (Comparatove Fit Index), RMSEA (Root Mean Square Error of Approximation)으로 검증하였다.

\section{연구결과}

\section{보육교사의 효능감, 정서조절곤란 및 직무스트레스}

보육교사의 효능감, 정서조절곤란 및 직무스트레스의 정도를
파악하기 위해 평균과 표준편차를 구하였다. 그 결과 Table 2 와 같이 보육교사의 효능감은 중간 이상의 수준을 보였으며 $(M=3.59, S D=.45)$, 정서조절곤란은 거의 중간 정도이었으 며 $(M=2.61, S D=.55)$, 직무스트레스도 중간 수준보다 약간 높은 것으로 나타났다 $(M=2.98, S D=.62)$. 각 변인들의 평균 을 하위요인별로 살펴보면, 보육교사효능감 중에서는 가정연 계 및 긍정적인 학습 환경 조성에 대한 효능감의 평균이 가장 높았고 $(M=3.89, S D=.57)$ 지역사회 연결에 대한 효능감의 평균이 가장 낮았으며 $(M=3.28, S D=.75)$, 정서조절곤란 중 에서는 목표지향적 행동의 어려움의 평균이 가장 높았으며 $(M$ $=2.76, S D=.78)$ 정서적 명료성 부족의 평균이 가장 낮았다 $(M$ $=2.21, S D=.83)$. 직무스트레스 중에서는 업무 과부하에 대한 스트레스 평균이 가장 높았고 $(M=3.53, S D=.76)$ 동료와의 관 계에 대한 스트레스 평균이 가장 낮았다 $(M=2.39, S D=.81)$.

\section{보육교사효능감과 직무스트레스의 관계에서 정서조절능력의 조절효과}

Ping (1996)의 2단계 접근방식을 이용하여 조절효과를 검증하 기 위해서는 관측변인의 정상성과 상관관계를 우선적으로 살 펴보아야 한다. 관측 변인의 정상성은 왜도와 첨도를 통해 확 인하는데, 왜도 < 2 , 첨도 < 7이면 정규분포 기준에 적합하다고 할 수 있다(Curran, West, \& Finch, 1996). Table 2와 같이 본 연 구의 관측변인들 가운데, 보육교사효능감의 '지역기관 연계' 가 직무스트레스의 모든 하위요인들과 상관관계를 보이지 않 았으며, 보육교사효능감의 '교수방법'과 정서조절곤란의 '정서 적 명료성 부족'은 정규분포를 나타내지 않았으므로 이 세 변 인을 분석에서 제외하였다. 그 외 보육교사의 직무스트레스의 하위요인들과 정적 또는 부적상관관계를 보인 교사효능감과 정서조절곤란의 하위요인 간의 상관계수 범위는 -.29-.68이 었으며, 유의수준 .05-.01 범위에서 통계적으로 유의하였다.

조절효과를 검증하기 위한 Ping (1996)의 2단계 접근방식 에서 1단계는 구축한 측정모형(Figure 1)의 적합지수를 확인 하고, 요인부하량, 분산, 오차분산 및 잠재변인 간의 상관관계 를 확인하는 것이다. 측정모형의 적합지수는 $\mathrm{GFI}=.93, \mathrm{CFI}=$ $.91, \mathrm{RMSEA}=.06$ 이어서 이 모형은 수용할 만 하였다.

Table 3은 측정모형의 계수 추정치를 나타낸 것인데, 각 잠 재변인에 대한 관측변인의 요인부하량은 $.40-.92$ 로 모두 유 의수준 .001에서 통계적으로 유의하였다. 이는 측정모델에서 구성된 보육교사의 효능감, 정서조절곤란, 직무스트레스 등의 잠재변인에 대한 각 관측변인들이 모두 타당하다는 것을 의미 
Table 2

Descriptive Statistics for and Intercorrelations Between Teacher Efficacy, Emotional Dysregulation, and Job Stress of Teachers in Early Childhood Education and Care

\begin{tabular}{|c|c|c|c|c|c|c|c|c|c|c|c|c|c|c|}
\hline & \multicolumn{4}{|c|}{ Teacher efficacy } & \multicolumn{6}{|c|}{ Emotional dysregulation } & \multicolumn{4}{|c|}{ Job stress } \\
\hline & $\mathrm{a}$ & $\mathrm{b}$ & c & d & $\mathrm{e}$ & $\mathrm{f}$ & $\mathrm{g}$ & $\mathrm{h}$ & $\mathrm{i}$ & $\mathrm{j}$ & $\mathrm{k}$ & 1 & $\mathrm{~m}$ & $\mathrm{n}$ \\
\hline $\mathrm{a}$ & - & & & & & & & & & & & & & \\
\hline $\mathrm{b}$ & $.57^{* *}$ & - & & & & & & & & & & & & \\
\hline c & $.44^{* *}$ & $.30^{* *}$ & - & & & & & & & & & & & \\
\hline d & $.47^{* *}$ & $.47^{* *}$ & $.28^{* *}$ & - & & & & & & & & & & \\
\hline e & $-.30^{* *}$ & $-.22^{* *}$ & $-.12^{* *}$ & $-.17^{* *}$ & - & & & & & & & & & \\
\hline $\mathrm{f}$ & $-.41^{* *}$ & $-.36^{* *}$ & $-.14^{* *}$ & $.29^{* *}$ & $.37^{* *}$ & - & & & & & & & & \\
\hline g & $-.14^{* *}$ & -.08 & -.04 & -.05 & $.63^{* *}$ & $.28^{* *}$ & - & & & & & & & \\
\hline $\mathrm{h}$ & $-.29^{* *}$ & $-.26^{* *}$ & -.06 & $-.16^{* *}$ & $.55^{* *}$ & $.42^{* *}$ & $.46^{* *}$ & - & & & & & & \\
\hline $\mathrm{i}$ & $-.31^{* *}$ & $-.19^{* *}$ & -.08 & $-.17^{* *}$ & $.70^{* *}$ & $.36^{* *}$ & $.71^{* *}$ & $.56^{* *}$ & - & & & & & \\
\hline j & $-.21^{* *}$ & $-.19^{* *}$ & -.07 & $-.10^{* *}$ & $.62^{* *}$ & $.20^{* *}$ & $.55^{* *}$ & $.36^{* *}$ & $.66^{* *}$ & - & & & & \\
\hline $\mathrm{k}$ & $-.24^{* *}$ & $-.16^{* *}$ & .04 & $-.29^{* *}$ & $.17^{* *}$ & $.12^{* *}$ & .06 & $.14^{* *}$ & $.18^{* *}$ & $.10^{*}$ & - & & & \\
\hline 1 & $-.14^{* *}$ & -.08 & .05 & $-.13^{* *}$ & $.16^{* *}$ & $.09^{*}$ & .04 & $.10^{*}$ & $.14^{* *}$ & $.15^{* *}$ & $.63^{* *}$ & - & & \\
\hline $\mathrm{m}$ & $-.17^{* *}$ & $-.13^{* *}$ & .07 & $-.13^{* *}$ & $.23^{* *}$ & $.14^{* *}$ & $.14^{* *}$ & $.21^{* *}$ & $.25^{* *}$ & $.14^{* *}$ & $.60^{* *}$ & $.39^{* *}$ & - & \\
\hline $\mathrm{n}$ & $-.13^{* *}$ & -.08 & .06 & -.06 & $.18^{* *}$ & .06 & .07 & $.12^{* *}$ & $.17^{* *}$ & $.20^{* *}$ & $.47^{* *}$ & $.68^{* *}$ & $.41^{* *}$ & - \\
\hline $\bar{M}$ & 3.89 & 3.58 & 3.28 & 3.56 & 2.26 & 2.37 & 2.53 & 2.21 & 2.27 & 2.76 & 2.59 & 3.53 & 2.39 & 3.37 \\
\hline$S D$ & .57 & .57 & .75 & .66 & .71 & .50 & .66 & .83 & .69 & .78 & .76 & .76 & .81 & .81 \\
\hline Skewness & -.82 & 1.07 & -.24 & -.12 & .54 & .15 & .10 & 3.53 & .34 & .05 & -.10 & -.52 & .24 & .22 \\
\hline Kurtosis & 5.19 & 20.15 & 1.11 & 3.50 & 1.46 & 1.69 & .14 & 41.22 & .07 & .16 & -.32 & .13 & -.21 & 2.60 \\
\hline$M(S D)$ & & 3.59 & $(.45)$ & & & & 2.61 & (.55) & & & & 2.98 & $(.62)$ & \\
\hline
\end{tabular}

Note. $N=586 . \mathrm{a}=$ home connection and promotion of positive learning environment; $\mathrm{b}=$ teaching methods; $\mathrm{c}=$ community connection; $\mathrm{d}=$ decision makings; $\mathrm{e}=$ impulse control difficulties (impulse); $\mathrm{f}=$ lack of attention to and awareness of emotions (awareness); $\mathrm{g}=$ nonacceptance of emotions (nonacceptance); $\mathrm{h}=$ lack of emotional clarity (clarity); $\mathrm{i}=$ limited access to emotional regulation strategies (strategies); $\mathrm{j}$ = difficulties in engaging in goal-directed behavior (goals); $\mathrm{k}$ = insufficiency of director's leadership and administrative support; $\mathrm{l}=$ work overload; $\mathrm{m}=$ relation with colleagues; $\mathrm{n}=$ relation with parents.

${ }^{*} p<.05 .{ }^{* *} p<.01$.

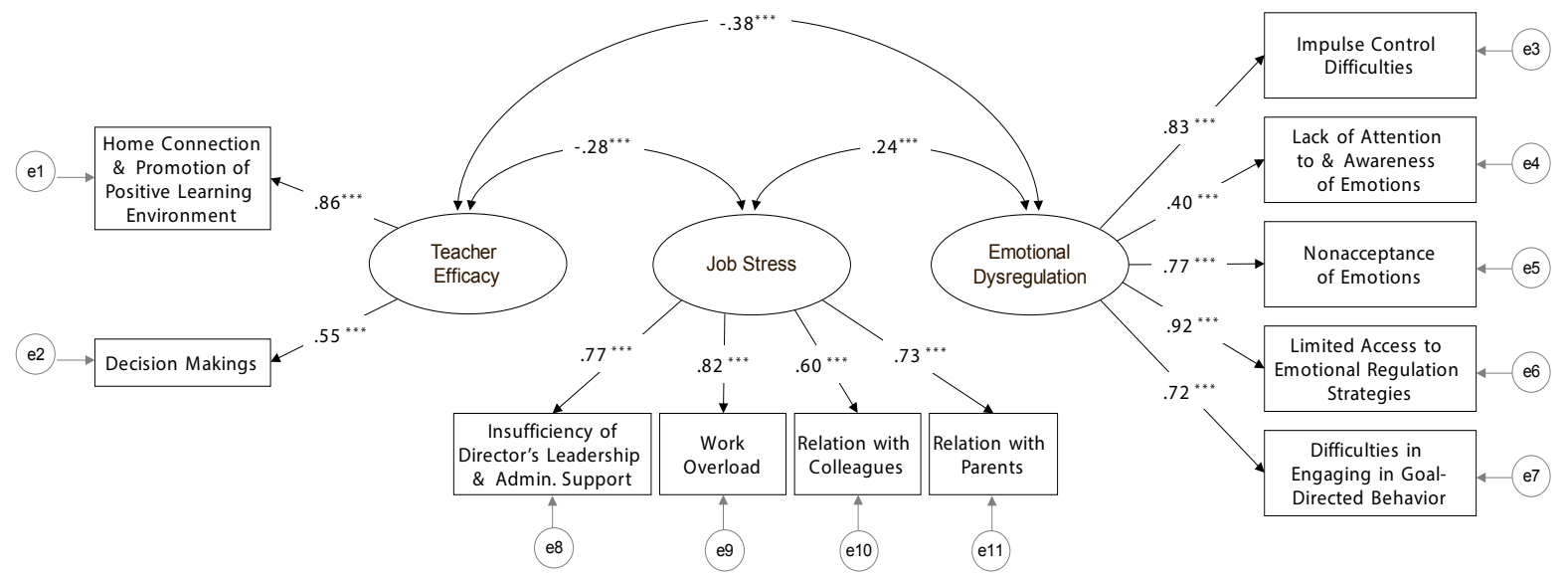

Figure 1. Measurement model.

${ }^{* * *} p<.001$. 
Table 3

Estimation of Coefficients in the Measurement Model

\begin{tabular}{|c|c|c|c|c|c|c|c|c|}
\hline Latent variables & & Manifest variables & $B$ & $\beta$ & $S E$ & $t$ & Variances & $\begin{array}{c}\text { Error } \\
\text { variances }\end{array}$ \\
\hline \multirow[t]{2}{*}{ Teacher efficacy } & $\longrightarrow$ & $\begin{array}{l}\text { Home connection and promotion of positive } \\
\text { learning environment }\end{array}$ & 1.00 & .86 & & & .20 & .03 \\
\hline & $\rightarrow$ & Decision makings & .76 & .55 & .13 & $5.85^{* * *}$ & & .03 \\
\hline \multirow[t]{5}{*}{ Emotional dysregulation } & $\longrightarrow$ & Impulse control difficulties & 1.00 & .83 & & & .36 & .01 \\
\hline & $\rightarrow$ & $\begin{array}{l}\text { Lack of attention to and awareness } \\
\text { of emotions }\end{array}$ & .34 & .40 & .04 & $9.51^{* * *}$ & & .01 \\
\hline & $\longrightarrow$ & Nonacceptance of emotions & .85 & .77 & .04 & $20.72^{* * *}$ & & .01 \\
\hline & $\longrightarrow$ & $\begin{array}{l}\text { Limited access to emotional regulation } \\
\text { strategies }\end{array}$ & 1.06 & .92 & .04 & $25.81^{* * *}$ & & .01 \\
\hline & $\rightarrow$ & $\begin{array}{l}\text { Difficulties in engaging in goal-directed } \\
\text { behavior }\end{array}$ & .94 & .72 & .05 & $19.10^{* * *}$ & & .02 \\
\hline \multirow[t]{4}{*}{ Job stress } & $\rightarrow$ & $\begin{array}{l}\text { Insufficiency of director's leadership and } \\
\text { administrative support }\end{array}$ & 1.00 & .77 & & & .33 & .02 \\
\hline & $\rightarrow$ & Work overload & 1.07 & .82 & .06 & $17.67^{* * *}$ & & .02 \\
\hline & $\longrightarrow$ & Relation with colleagues & .84 & .60 & .06 & $13.34^{* * *}$ & & .03 \\
\hline & $\longrightarrow$ & Relation with parents & 1.01 & .73 & .06 & $16.25^{* * *}$ & & .02 \\
\hline
\end{tabular}

${ }^{* * *} p<.001$.

Table 4

Correlations Between Latent Variables

\begin{tabular}{lcccc}
\hline & Coefficients path & Covariance & Correlation \\
\hline Teacher efficacy & $\leftrightarrow$ & Job stress & -.07 & $-.28^{* * *}$ \\
Teacher efficacy & $\leftrightarrow$ & Emotional dysregulation & -.10 & $-.38^{* * *}$ \\
Emotional dysregulation & $\leftrightarrow$ & Job stress & .08 & $.24^{* * *}$ \\
\hline
\end{tabular}

${ }^{* * *} p<.001$.

한다.

잠재변인들 간의 경로에 대한 상관관계는 Table 4 와 같이 보육교사효능감은 직무스트레스 $(r=-.28, p<.001)$, 정서조절 곤란 $(r=-.38, p<.001)$,과 각각 부적인 상관관계를, 정서조절 곤란과 직무스트레스는 정적인 상관관계 $(r=.24, p<.001)$,를 보였다.

조절효과를 검증하기 위한 Ping (1996)의 2단계 접근방식 에서 2 단계는 1 단계에서 산출한 주효과변인인 보육교사효능 감과 조절효과변인인 정서조절곤란의 분산과 측정오차 분산 (Table 3)을 이용하여 상호작용항의 분산과 상호작용항 지표 변인의 요인계수 및 오차분산을 계산하여 모형을 검증하고 적 합지수를 확인하는 것이다. 이 계산으로 얻은 상호작용항의 분산값 .08, 상호작용항 지표변인의 요인계수 .51 , 상호작용항 지표변인의 오차분산 .04를 각각 조절모형(Figure 2)에 고정시
킨 후 검증한 결과는 Table 5 와 같다. 보육교사효능감이 직무 스트레스에 영향을 미치는 경로 $(\beta=-.68, p<.001)$, 정서조절 곤란이 직무스트레스에 영향을 미치는 경로 $(\beta=.53, p<.01)$, 보육교사의 효능감과 정서조절곤란의 상호작용이 직무스트 레스에 영향을 미치는 경로 $(\beta=.78, p<.01)$ 가 모두 통계적으 로 유의하였다. 이 조절모형의 적합지수는 $\mathrm{GFI}=.92, \mathrm{CFI}=$ $.91, \mathrm{RMSEA}=.06$ 이어서 조절모형은 수용할 만 기준을 넘는 것으로 나타났다.

\section{논의 및 결론}

이 연구는 보육교사의 효능감, 정서조절곤란 및 직무스트레스 의 수준을 알아보고, 보육교사의 효능감이 직무스트레스에 영 


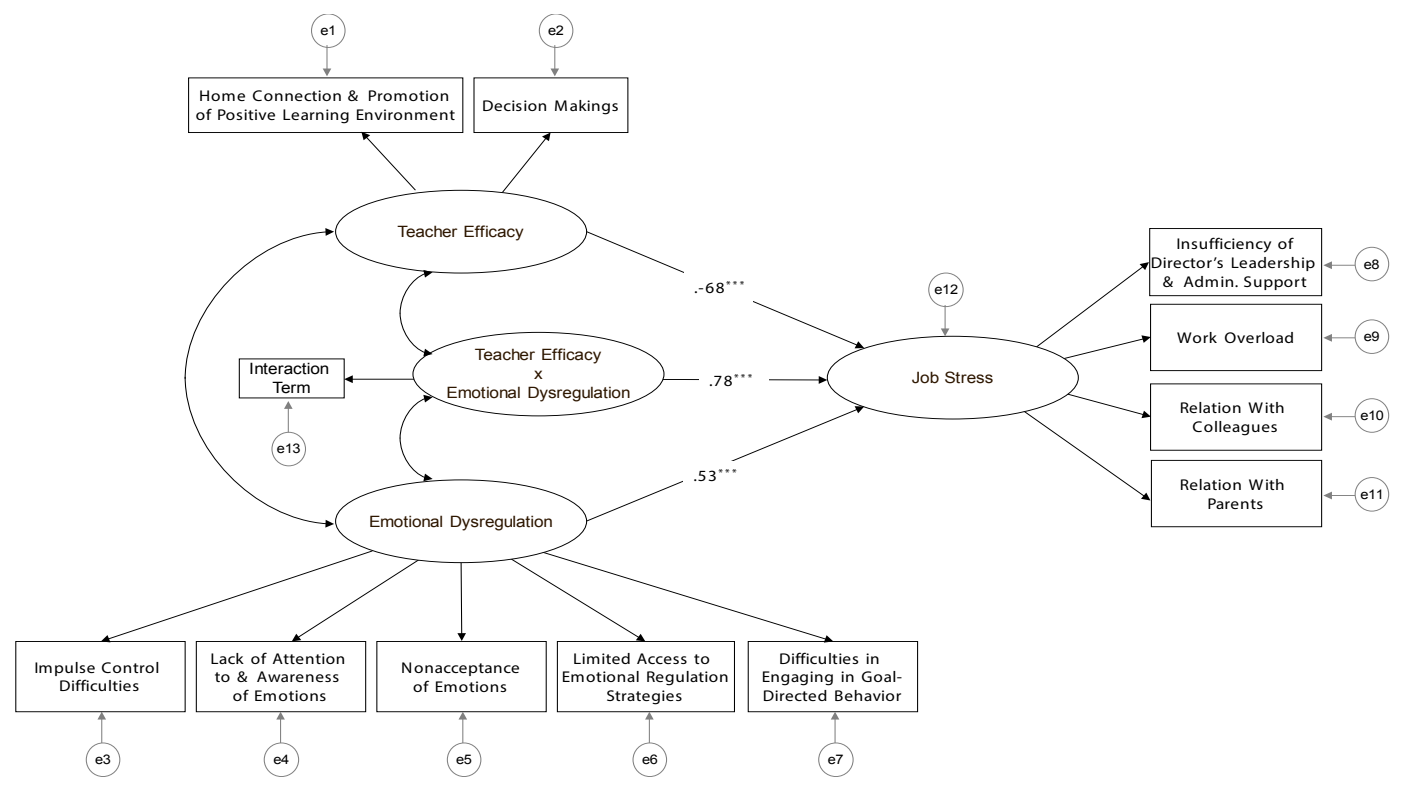

Figure 2. Moderation model.

${ }^{* * *} p<.001$.

Table 5

Estimation of the Coefficients of the Moderating Effect in the Interaction Model

\begin{tabular}{|c|c|c|c|c|c|c|}
\hline \multicolumn{3}{|c|}{ Coefficients path } & \multirow{2}{*}{$\begin{array}{c}B \\
-.93\end{array}$} & \multirow{2}{*}{$\begin{array}{c}\beta \\
-.68\end{array}$} & \multirow{2}{*}{$\begin{array}{c}S E \\
.28\end{array}$} & \multirow{2}{*}{$\begin{array}{c}t \\
-3.34^{* * *}\end{array}$} \\
\hline Teacher efficacy & $\rightarrow$ & Job stress & & & & \\
\hline Emotional dysregulation & $\rightarrow$ & Job stress & .50 & .53 & .24 & $-2.06^{* * *}$ \\
\hline
\end{tabular}

${ }^{* * *} p<.001$.

향을 미치는 관계에서 정서조절곤란이 조절효과를 보이는지 를 검증하기 위해 실시되었다. 앞서 언급한 연구결과를 바탕 으로 논의하면 다음과 같다.

첫째, 보육교사의 효능감과 직무스트레스의 수준은 모두 중간 이상이었으며 정서조절곤란은 중간 정도인 것으로 나타 났다. 이는 보육교사의 효능감이 중간 이상이라고 보고한 $S$. -H. Lee와 Park (2007)과 Yoo 등(2011)의 연구결과와 비슷한 것 으로 영유아를 돌보고 교육하는 주요 임무 외에도 여러 가지 역할을 동시에 하며 능력을 발휘해야 하는 보육교사로서 역할 수행에 중간 수준 이상의 믿음과 자신감을 가지고 있다는 뜻 이다. 특히 가정연계 및 긍정적인 학습 환경 조성에 대한 효능 감의 수준이 제일 높아서 여러 영유아들과 하루 일과 중 많은 시간을 함께 보내는 제 2 의 어머니로서 가장 중요시 되는 학급 운영에 대한 긍정적인 믿음과 자신감을 갖고 있다는 것은 바 람직한 것이라고 할 수 있다. 또한 보육교사의 직무스트레스
수준과 하위요인 가운데에서도 업무 과부하에 대한 수준이 가 장 높다는 본 연구의 결과는 앞서 이루어진 연구의 결과(Shin, 2004)와 일치하였다. 보육교사의 가장 중요한 업무인 영유아 와의 긍정적인 관계 형성을 저해하는 불필요한 잡무 또는 과 도한 서류 업무 등을 감소시키는 것이 보육교사의 직무스트레 스를 낮추고 보육의 질을 향상시킬 수 있는 방안일 것이다. 일 부 지자체에서는 보육교사의 직무스트레스를 낮추기 위한 방 안으로 서류 업무를 간소화하려는 시도가 있으나, 자치구를 통한 권고사항인 관계로 실행에 있어 한계가 있다. 따라서 형 식적인 제안이 아닌 실효성이 높은 제도를 마련하는 것이 궁 극적으로 영유아에게 양질의 보육을 제공하는 길이 될 것이 다. 한편 보육교사는 거의 중간정도의 수준으로 정서조절곤란 을 겪고 있음을 알 수 있다. 국내 보육교사의 정서조절곤란을 측정한 선행연구가 없어 이전 연구와 직접적으로 비교하는 것 은 불가하지만, 이 연구를 통해 얻은 결과를 미루어볼 때, 중등 
교사의 정서조절곤란(Lim \& Do, 2014) 수준에 비해 보육교사 의 정서조절곤란 수준은 조금 높은 것이었다. 보육교사는 정 서조절곤란의 하위요인 중에서 목표지향적 행동에 대한 어려 움이 가장 큰 것으로 나타났는데, 이는 부정적인 감정을 경험 하는 동안에는 집중을 하거나 성과를 이루어내는 것을 가장 어렵다고 여기는 것을 의미한다(Gratz \& Roemer, 2004). 정서 조절곤란과 관련된 환경적 요인으로 개인의 정서에 대한 주변 의 반응을 들 수 있다(Denham, Bassett, \& Wyatt, 2007). 부정적 정서표현을 하였을 경우, 주변인들로부터 이해를 받거나 공감 을 얻는다면 정서조절곤란을 낮출 수 있다는 뜻이다. 따라서 영유아와의 상호작용이 주업무인 보육교사직을 보다 성공적 으로 수행하기 위해서 보육교사가 자신의 정서조절곤란 수준 을 감소시켜 타인과 긍정적인 관계형성을 할 수 있도록 보육 기관 내에서 긍정적이고 서로 지지하는 근무환경을 조성하는 동시에 정서조절 능력을 향상시키기 위한 상담프로그램 및 워 크샵 등을 마련하고 이를 실행하기 위한 재원과 인력을 확충 해서 보육교사의 심리정서 관리에 사회적인 관심을 쏟아야 할 것이다.

둘째, 보육교사의 효능감이 직무스트레스에 영향을 미치 는 관계에서 정서조절곤란의 조절효과가 있었다. 즉, 보육교 사의 효능감이 직무스트레스에 부적 영향을 미치고 정서조절 곤란이 정적 영향을 미치는 가운데 보육교사의 효능감과 정서 조절곤란의 상호작용은 직무스트레스에 정적 영향을 미침으 로써 정서조절곤란은 이 두 변인의 관계에서 조절효과의 세 가지 유형 중 완화효과를 보였다. 이는 보육교사효능감이 높 은 경우 직무스트레스는 낮았지만, 이 때 정서조절곤란이 높 으면 보육교사효능감이 직무스트레스에 미치는 영향력이 감 소하여 직무스트레스가 낮아지는 폭 역시 감소하게 됨을 의미 한다. 이 세 변인을 한꺼번에 살펴본 연구를 찾아보기 힘든 실 정이어서 본 연구를 선행연구결과와 직접적으로 비교하는 것 은 불가하지만, 보육교사의 효능감이 높을수록 직무스트레스 가 낮다는 연구결과(Choi, 2015; H.-M. Lee, 2009; Schwarzer \& Hallum, 2008)와 교사가 정서조절에 곤란을 겪을수록 직무스 트레스가 높다는 연구결과(Lim \& Do, 2014)를 부분적으로 뒷 받침하는 것이다. 보육교사의 효능감이 직무스트레스에 영향 을 미치는 관계에서 정서조절곤란의 조절효과가 있었다는 보 육교사와 마찬가지로 주업무가 대인관계이어서 정서노동이 심한 직종 중 하나인 호텔근로자의 효능감과 감정 부조화로 인한 감정조절행위의 상호작용이 정신적 고갈에 영향을 미쳤 다는 연구결과 $(\mathrm{Ko}, 2010)$ 가 있어 큰 의미에서는 일맥상통한다 고 할 수 있겠다. 보육교사의 직무스트레스는 보육교사의 개
인만의 문제를 넘어서 보육교사가 하루 종일 상호작용을 해야 하는 영유아의 발달 및 정신건강에까지 부정적인 영향을 미치 게 된다. 본 연구의 결과는 보육교사의 직무스트레스를 낮출 수 있는 교사효능감은 높이고, 정서조절곤란의 수준은 낮출 수 있는 보다 근본적이고 현실적인 방안을 마련하여 건강한 영유아-보육교사 관계형성을 이루는 것이 진정한 보육의 질 적 향상이라는 것임을 시사한다.

앞서 언급한 바와 같이 보육교사의 직무스트레스와 관련된 교사효능감은 교사로서 학습자에게 도움을 줄 수 있는 자신의 능력에 대한 믿음과 자신감이다. 이러한 믿음과 자신감을 향 상시키기 위해서는 보육교사 양성교육과정에서 전문적인 지 식 및 기술을 습득하는 것도 중요하지만, 무엇보다도 보육현 장에서의 자원봉사의 기회나 실습기간 연장 등으로 현장 경험 을 가능한 한 많이 하여 이를 통해 자신의 능력에 대한 믿음과 자신감을 향상시킬 수 있는 교육과정을 마련하는 것이 중요할 것이다. 미국의 경우 영유아 교사 자격증을 획득하기 위해 2년 제 전문대학을 포함하여 4 년제 대학 교육과정에서는 최소 3 학기 이상의 현장 실습기간을 이수해야 한다. 반면, 국내 실정 은 4주 180 시간만의 실습과정이 의무이었다가 최근에 들어서 야 법이 개정되어 2017년 대학 입학자부터 6주 240시간 동안 보육현장 실습을 이수해야 하는 것으로 변경(MOHW, 2016b) 되었지만, 미국과 비교해 보았을 때에는 여전히 매우 부족하 다고 하겠다. 또한 최근 이루어진 한 연구에서는 보육교사의 적성과 책임이 효능감에 영향을 미친다는 결과를 보고하였다 (Chae, 2016). 따라서 보육교사의 기술적인 역량강화 뿐 아니 라 적성을 고려한 진로탐색 및 영유아를 담당하는 보육교사로 서의 중요한 역할에 대한 책임감 함양 등과 관련된 소양교육 을 통해 교사효능감을 향상시켜 직무스트레스를 낮추는 자생 (自生)능력을 형성할 수 있도록 양성 및 보수교육과정과 근무 환경을 제공해 주는 것이 보육의 질을 향상시키는 중요한 방 법 중 하나일 것이다.

한편 높은 교사효능감을 지닌 보육교사는 직무스트레스를 덜 경험하게 되지만, 이 과정에서 보육교사가 정서조절에 곤 란을 겪고 있다면 보육교사의 효능감이 직무스트레스를 낮추 는 영향이 감소된다는 이 연구의 결과는 보육교사의 정신건강 을 관리하는 것 역시 간과해서는 안 될 사항임을 시사한다. 즉 다양한 노력을 통해 보육교사의 효능감을 증가시킨다 하여도 보육교사가 자신의 정서를 조절함에 있어 곤란을 겪는다면 보 육교사효능감이 직무스트레스를 낮출 수 있는 영향력은 감소 될 것이다. 따라서 보육교사의 효능감을 향상시키는 동시에 정서조절능력 또한 향상시키는 노력이 필요하다. 원치 않는 
감정을 표현하는 것은 부정적인 행동이라는 생각에 내면에서 발생하는 이러한 심리적 경험들을 회피하려고 하는 것은 오히 려 심리정서장애의 원인이 되며(Hayes, Wilson, Gifford, Follette \& Strosahl, 1996), 과도한 정서 표현 통제는 정서조절곤란을 초래한다(Gross \& Levenson, 1997). 이러한 심리적 부적응이 직무스트레스를 낮출 수 있는 보육교사의 효능감의 영향을 감 소시킨다는 것은 정서조절곤란으로 인해 직무스트레스가 가 중될 수도 있음을 시사하는 것이다. 따라서 보육교사의 정서 조절능력을 향상시킬 수 있는 상담프로그램 및 명상프로그램 등을 제공하고 보육교사는 이를 통해 자신의 정서를 지각하고 이해해서 수용하고, 부정적인 정서를 경험할 때 충동적인 행 동을 조절하여 개인이 바라는 목표에 일치되게 행동하는 능력 을 향상시키고, 자신의 목표와 처한 상황에 맞도록 정서적 반 응을 조절할 수 있는 정서조절전략을 융통성 있게 사용할 수 있는 정서조절능력(Y. Cho, 2007; Gratz \& Roemer, 2004)을 향 상시켜 정서조절곤란을 낮춘다면 직무스트레스 역시 낮아질 것이다.

그러나 보육교사 자신만이 노력하는 것으로만으로는 정서 조절능력이 향상되지는 않을 가능성도 있다. 자신의 정서를 표현하였을 때 주변에서 그 정서적 반응을 수용하고 가치 있 게 여겨주는 과정을 통해 개인의 정서조절은 더 향상되어지는 반면, 자신의 정서표현이 받아들여지지 않는다면 정서조절에 곤란을 겪기 때문이다(Paivio \& Greenberg, 1998). 그러므로 담 당해야 할 많은 수의 영유아와 학부모와의 상호작용 등 여러 가지 능력이 동시에 요구되는 육체적 노동 뿐 아니라 정서노 동이 심한 보육교사 역할을 수행하는 동안 직장 내에서 다소 부정적인 정서를 표현하더라도 동료들로부터 지지와 공감 및 이해를 받을 수 있는 친근하고 수용적인 분위기가 조성된다면 보육교사의 정서조절곤란을 완화시킬 수 있고, 직무스트레스 가 낮아질 것이며, 이로 인해 보육의 질은 향상될 것으로 기대 할 수 있다.

근래에 아동학대 등으로 보육교사의 자질 및 역할에 대한 사회의 관심이 집중되는 상황에서 보육교사의 직무스트레스 에 정적인 영향과 부적인 영향을 미치는 요인들 간의 관계를 살펴보는 동시에 그 중요성을 강조할 수 있는 결과를 얻었다 는 것은 사회적으로나 학문적으로 의미 있는 일이다. 또한 그 간 이루어지지 않았던 보육교사의 정서조절곤란을 측정하여 그 결과에 대해 논의하였다는 것 역시 이 연구의 학문적 의의 일 것이다. 그러나 차후 연구에서는 다면적인 시각을 가지고 더 많은 변인들 간의 관계를 동시에 고려해 보고, 심층면접을 통해 보다 다양한 형태의 자료를 함께 제시한다면 보육교사의
직무스트레스에 관해 더욱 깊은 이해를 할 수 있을 것이며, 이 를 바탕으로 보다 근본적인 제도를 마련할 수 있을 것이다.

\section{Acknowledgements}

This study was supported by the 2015 research grant of Division of Childcare Infrastructure in Ministry of Health and Welfare (policy research project 11-1352000-001654-01).

\section{Notes}

This article was presented at the 2016 Annual Spring Conference of the Korean Association of Child Studies in Seoul, Korea.

\section{Conflict of Interest}

No potential conflict of interest relevant to this article was reported.

\section{References}

\section{In English}

Aldea, M. A., \& Rice, K. G. (2006). The role of emotional dysregulation in perfectionism and psychological distress. Journal of Counseling Psychology, 53(4), 498-510. doi:10.1037/0022-0167.53.4.498

Bandura, A. (1977). Self-efficacy: Toward a unifying theory of behavioral change. Psychological Review, 84(2), 191-215. doi:10.1037/0033-295X.84.2.191

Bandura, A. (2006). Guide for constructing self-efficacy scales. In F. Pajares \& T. C. Urdan (Eds.), Self-efficacy beliefs of adolescents (pp. 307-337). New York: H. H. Freeman.

Catanzaro, S. J., \& Laurent, J. (2004). Perceived family support, negative mood regulation expectancies, coping and adolescent alcohol use: Evidence of meditation and moderation effects. Addictive Behaviors, 29(9), 1779-1797. doi:10.1016/j.addbeh.2004.04.001

Chan, D. W. (2004). Perceived emotional intelligence and selfefficacy among Chinese secondary school teachers in Hong Kong. Personality and Individual Differences, 36(8), 17811795. doi:10.1016/j.paid.2003.07.007 
Chan, D. W. (2008). General, collective, and domain-specific teacher self-efficacy among Chinese prospective and in-service teachers in Hong Kong. Teaching and Teacher Education, 24(4), 1057-1069. doi:10.1016/j.tate.2007.11.010

Chang, M.-L. (2009). An appraisal perspective of teacher burnout: Examining the emotional work of teachers. Educational Psychology Review, 21(3), 193-218. doi:10.1007/s10648009-9106-y

Cicchetti, D., Ackerman, B. P., \& Izard, C. E. (1995). Emotions and emotion regulation in developmental psychopathology. Development and Psychopathology, 7(1), 1-10. doi:10.1017/ S0954579400006301

Collie, R. J., Shapka, J. D., \& Perry, N. E. (2012). School climate and social-emotional learning: Predicting teacher stress, job satisfaction, and teaching efficacy. Journal of Educational Psychology, 104(4), 1189-1204. doi:10.1037/a0029356

Crouch, J. L., \& Behl, L. E. (2000). Relationships among parental beliefs in corporal punishment, reported stress, and physical child abuse potential. Child Abuse \& Neglect, 25(3), 413419. doi:10.1016/S0145-2134(00)00256-8

Cukur, C. S. (2009). The development of the teacher emotional labor scale (TELS): Validity and Reliability. Educational Sciences: Theory and Practice, 9(2), 559-574. Retrieved from http://eric.ed.gov/?id=EJ847767

Curran, P. J., West, S. G., \& Finch, J. (1996). The robustness of test statistics to non-normality and specification error in confirmatory factor analysis. Psychological Methods, 1(1), 16-29. doi:10.1037/1082-989X.1.1.16

Denham, S. A., Bassett, H. H., \& Wyatt, T. (2007). The socialization of emotional competence. In J. E. Grusec \& P. D. Hastings (Ed.), Handbook of socialization: Theory and research (pp. 614-637). London: The Guilford Press.

Freeman, N. K., \& Feeney, S. (2016). What teachers need to know: Professional ethics. In L. J. Couse \& S. L. Recchia (Eds.), Handbook of early childhood teacher education (pp. 148162), New York: Routledge.

Gibson, S., \& Dembo, M. H. (1984). Teacher efficacy: A construct validation. Journal of Educational Psychology, 76(4), 569582. doi:10.1037/0022-0663.76.4.569

Goddard, R. D., Hoy, W. K., \& Hoy, A. W. (2000). Collective teacher efficacy: Its meaning, measure, and impact on student achievement. American Educational Research Journal, 37(2), 479-507. doi:10.3102/00028312037002479

Gratz, K. L., \& Roemer, L. (2004). Multidimensional assessment of emotion regulation and dysregulation: Development, factor structure, and initial validation of the difficulties in emotion regulation scale. Journal of Psychopathology and Behavioral Assessment, 26(1), 41-54. doi:10.1023/ B:JOBA.0000007455.08539.94

Gross, J. J., \& Levenson, R. W. (1997). Hiding feelings: The acute effects of inhibiting negative and positive emotion. Journal of Abnormal Psychology, 106(1), 95-103. doi:10.1037/0021843X.106.1.95

Hayes, S. C., Wilson, K. C., Gifford, E. V., Follette, V. M., \& Strosahl, K. (1996). Experiential avoidance and behavioral disorders: A functional dimensional approach to diagnosis and treatment. Journal of Consulting and Clinical Psychology, 64(6), 1152-1168. doi:10.1037/0022-006X.64.6.1152

Herts, K. L., McLaughlin, K. A., \& Hatzenbuehler, M. L. (2012). Emotion dysregulation as a mechanism linking stress exposure to adolescent aggressive behavior. Journal of Abnormal Child Psychology, 40(7), 1111-1122. doi:10.1007/ s10802-012-9629-4

Kaiser, J. S., \& Polczynski, J. J. (1982). Educational stress: Sources, reactions, prevention. Peabody Journal of Education, 59(2), 127-136. doi:10.1080/01619568209538364

Klassen, R. M., Foster, R. Y., Rajani, S., \& Bowman, C. (2009). Teaching in the Yukon: Exploring teachers' efficacy beliefs, stress, and job satisfaction in a remote setting. International Journal of Educational Research, 48(6), 381-394. doi:10.1016/ j.ijer.2010.04.002

Kovess-Masfety, V., Rios-Seidel, C., \& Sevilla-Dedieu, C. (2007). Teachers' mental health and teaching levels. Teaching and Teacher Education, 23(7), 1177-1192. doi:10.1016/ j.tate.2006.07.015

Kring, A. M., \& Werner, K. H. (2013). Emotion regulation and psychopathology. In P. Philippot, \& R. S. Feldman (Eds.), The regulation of emotion. (pp. 365-392). Psychology Press: New York.

Leach, D. J. (1984). A model of teacher stress and its implications for management. Journal of Educational Administration, 22(2), 157-172. doi:10.1118/eb009891

MacKinnon, D. P., \& Leucken, L. J. (2008). How and for whom? Mediation and moderation in health psychology. Health Psychology, 27(2 Suppl), S99-S100. doi:10.1037/02786133.27.2(Suppl.).S99

Margolis, B. L., Kroe, W. H., \& Quinn, R. P. (1974). Job stress: An unlisted occupational hazard. Journal of Occupational Medicine, 16(10), 659-661. doi:10.1016/00036870(76)90020-X

Mearns, J., \& Cain, J. E. (2003). Relationships between teachers' occupational stress and their burnout and distress: Roles of coping and negative mood regulation expectancies. Anxiety, Stress \& Coping, 16(1), 71-82. doi:10.1080/106158002100 0057040

Motowidlo, S. J., Packard, J. S., \& Manning, M. R. (1986). Occupational stress: Its causes and consequences for job performance. Journal of Applied Psychology, 71(4), 618-629. doi:10.1037/0021-9010.71.4.618

Paivio, S. C., \& Greenberg, L S. (1998). Experiential theory of 
emotion applied to anxiety and depression. In W. F. Flack Jr. \& J. D. Laird (Eds.), Emotions in psychopathology: Theory and research (pp. 229-242). New York: Oxford University Press.

Ping, R. A. (1996). Latent variable interaction and quadratic effect estimation: A two-step technique using structural equation analysis. Psychological Bulletin, 119(1), 166-175. doi:10.1037/0033-2909.119.1.166

Recchia, S. L. (2016). Preparing teachers for infant care and education. In L. J. Couse \& S. L. Recchia (Eds.), Handbook of early childhood teacher education (pp. 89-103), New York: Routledge.

Reid, R. C., Bramen, J. E., Anderson, A., \& Cohen, M. S. (2014). Mindfulness, emotional dysregulation, impulsivity, and stress proneness among hypersexual patients. Journal of Clinical Psychology, 70(4), 313-321. doi:10.1002/jclp.22027

Schumacker, R. E., \& Lomax, R. G. (2015). A beginners' guide to structural equation modeling ( 4 th ed.). New York: Routledge.

Schwarzer, R., \& Hallum, S. (2008). Perceived teacher self-efficacy as a predictor of job stress and burnout: Mediation analyses. Applied Psychology: An International Review, 57(Supplement 1), 152-171. doi:10.1111/j.1464-0597.2008.00359.x

Suveg, C., \& Zeman, J. (2004). Emotion regulation in children with anxiety disorders. Journal of Clinical Child and Adolescent Psychology, 33(4), 750-759. doi:10.1207/ s15374424jccp3304_10

Tschannen-Moran, M., \& Hoy, A. W. (2001). Teacher efficacy: Capturing and elusive construct. Teaching and Teacher Education, 17(7), 783-805. doi:10.1016/S0742051X(01)00036-1

Tschannen-Moran, M., Hoy, A. W., \& Hoy, W. K. (1998). Teacher efficacy: Its meaning and measure. Review of Educational Research, 68(2), 202-248. doi:10.3102/00346543068002202

\section{In Korean}

Bae, B. R. (2015). Analyses of moderating and mediation effects with SPSS/Amos/LISREL/SmartPLS. Seoul: Chungram Publishing.

Chae, J.-Y. (2016). The influence of teachers' vocational aptitude and sense of responsibility on their teaching efficacy in early childhood education and care. Korean Journal of Childcare and Education, 12(2), 57-72. doi:10.14698/ jkcce.2016.12.02.057

Cho, Y. (2007). Assessing emotion dysregulation: Psychometric properties of the Korean version of the difficulties in emotion regulation scale. The Korean Journal of Clinical Psychology, 26(4), 1015-1038. Retrieved from http://www. riss.kr/link?id=A100627303
Cho. S. Y. (2005). A job stress and self-efficacy of child care teachers. Korean Journal of Child Studies, 26(4), 55-70. Retrieved from http://www.riss.kr/link?id=A353433

Choi, E. H. (2015). The effect of private kindergarten teacher's teacher efficacy and communication competence on job stress. Korean Journal of Childcare and Education, 11(2), 3957. doi:10.14698/jkcce.2015.11.2.039

Han, K. S., Park, Y. J., Kim, K. M., Oh, Y. J., Jin, J. H., \& Kang, H. C. (2008). Communication style, self efficacy, emotional regulation, and ways of coping among nursing students. Journal of Korean Academy of Psychiatric and Mental Health Nursing, 17(1), 28-34. Retrieved from http://www.riss.kr/ link?id=A5101838

Kim, Y.-M., \& Kang, J.-Y. (2015). The moderating effects of job stress in the relationship between parenting attitudes experienced in childhood by child care teachers and child abuse in child care center. Journal of the Korean Society of Child Welfare, 51, 133-161. Retrieved from http://www. riss.kr/link?id=A101103705

Kim, Y. H., \& Kim, Y. E. (2008). An analysis of the factorial validity of Bandura's teacher self-efficacy scale. Korean Journal of Early Childhood Education, 28(2), 169-191. Retrieved from http://www.riss.kr/link?id=A99534997

Ko, J.-S. (2010). A study on the modification variable of emotional dissonance and burnout by self efficacy. Korean Business Education Review, 64, 335-359. Retrieved from http:// www.riss.kr/link?id=A99619149

Kwon, H.-J. (2009). Childcare center teachers' emotional labor and emotional exhaustion: The moderating effects of emotional display rules. Early Childhood Education Research \& Review, 13(6), 255-276. Retrieved from http://www.riss.kr/ link?id=A76618830

Lee, H.-M. (2009). Effects of child care teachers' sense of efficacy and belief on job stress. Korea Journal of Child Care and Education, 56(3), 187-208. Retrieved from http://www.riss. $\mathrm{kr} /$ link?id=A76366227

Lee, J.-Y., \& Kwon, S.-M. (2007). Development of the emotion regulation strategy questionnaire. The Korean Journal of Clinical Psychology, 26(4), 963-976. Retrieved from http:// www.riss.kr/link?id=A100627300

Lee, K.-S., Kim, M. S., Chae, J.-Y., Park, J., \& Yoon, Y. S. (2015). Development of a counseling program to control job stress of child care teachers. Retrieved from http://www.prism.go.kr/

Lee, S.-H., \& Park, Y.-S. (2007). A study on child care teachers' efficacy and job satisfaction. The Journal of Korea Open Association for Early Childhood Education, 12(1), 31-50. Retrieved from http://www.riss.kr/link?id=A75129880

Lim, J.-Y., \& Do, S.-L. (2014). The effects of middle and high school teachers' emotion regulation on job stress, burnout, and teacher-efficacy. Korean Journal of Thinking Development, 
10(1), 105-126. Retrieved from http://www.riss.kr/ link?id=A100001895

Ministry of Health and Welfare. (2016a). 2015 Statistics for childcare. Retrieved from http://www.mohw.go.kr/

Ministry of Health and Welfare. (2016b). Reinforcement of certification standard for improving personality and qualification of teachers in early childhood education and care. Retrieved from http://www.mohw.go.kr/

Park, S.-M. (2013). The relation among the emotion-regulation ability, child-teacher relationship burnout of early childhood teachers. The Journal of Child Education, 22(1), 21-32. Retrieved from http://www.riss.kr/link?id=A99795431

Seo, D. M., \& Yeun, S.-Y. (2016). The relationship among day care center teacher's job stress, awareness and action by selfassessment of the infant abuse. Early Childhood Education Research \& Review, 20(1), 193-216. Retrieved from http:// www.riss.kr/link?id=A101805177

Seo, Y. S. (2010). Testing mediator and moderator effects in counseling psychology research: Conceptual distinction and statistical considerations. Korean Journal of Counseling and Psychotherapy, 22(4), 1147-1168. Retrieved from http:// www.riss.kr/link?id=A100630675

Shin, H. Y. (2004). Effects of teachers' job stress and belief of efficacy on the quality of teachers' interaction behavior in child care (Doctoral dissertation). Retrieved from http://www.riss.kr/ link?id=T9780798

Yoo, G. S., Kim, S. K., Kang, K. H., Park, J. H., \& Hwang, J. Y. (2011). Relationships among organizational culture of child care centers, teachers' background variables, teacher efficacy, and job stress of novice child care teachers. Journal of Future Early Childhood Education, 18(3), 81-104. Retrieved from http://www.riss.kr/link?id=A82634327

Yoon, H., \& Noh, P. S. (2013). Relationship of work stress, career commitment, burnout and turnover intention among educare teachers. Journal of the Korean Society of Child Welfare, 43, 157-184. Retrieved from http://www.riss.kr/ link?id=A99794695

\section{ORCID}

$\begin{array}{ll}\text { Kyung-Sook Lee } & \text { http://orcid.org/0000-0001-5898-7184 } \\ \text { Jin-Young Chae } & \text { http://orcid.org/0000-0003-4298-467X } \\ \text { JinAh Park } & \text { http://orcid.org/0000-0002-6534-3990 } \\ \text { Myung-Sik Kim } & \text { http://orcid.org/0000-0003-4607-6409 } \\ \text { Jeong Min Lee } & \text { http://orcid.org/0000-0003-1810-0053 }\end{array}$

Received June 30, 2016 Revision received August 22, 2016 Accepted August August 25, 2016 